\title{
イギリス滞在記
}

\section{The Life and Times in the United Kingdom}

\section{石田尚之}

\section{Naoyuki Ishida}

\section{1.はじめに}

ユニオンジャックと女王陛下。フィッシュアンド チップスにローストビーフ。パブでビール, 紅茶にス コーン。変わりやすい天気と分厚い雲。ビールズにス トーンズ，ブリティッシュロック。昔読んだシャーロ ックホームズにシェイクスピア。こんなステレオタイ プの知識しかないまま，上空から初めてイギリスを見 下ろしたときの高揚感と非現実感を, 今も時々思い出 す。一日の殆どが重たい雲で塞がれる空はとても憂鬱 だったけれど，たまさか見える青い空は途方もなく美 しかった。ちょっと疲れた時にふと目に留まった， 木々の鮮烈な緑, 艶やかな花の色に心が吸い込まれた とき，イギリスに暮らしているんだ，という実感が涌 き出てきた。

2006 年 2 月から 1 年間, 筆者はイギリス中部の リーズ大学に滞在する機会を得た。以前から漠とした 海外への志向だけはあったが, ある日突然, 自分の年 齢を考えて，早くしないと身動きがとれなくなるかも と慄然とし，とにかく上司に直談判して許しを得，研 究費から滞在費を捻出し恩師東谷公先生（京大）に留 学先を相談して念願の留学となったわけである。

短い滞在ではあったが，そこで得られた経験は何物 にも代えがたいものであった。イギリスで自分が感 じ，考えたことを緅ってみたい。

\section{2. リーズ大学と研究}

イギリスとリーズの概要については，三尾浩氏が本 誌 2003 年 10 月号の海外報告に非常に詳しくまとめて おられるので，ぜひそちらを参照いただきたい。リー ズは歴史的に羊毛業と工業を軸に，イギリス中部の要 所として発展した街であり，世界で初めての商業鉄道 はリーズに石炭を運ぶためのものだったそうである。 20 世紀半ばに産業の不振により一時衰退したが, 近 年になって主に金融業を積極的に誘致することで再び

(独) 産業技術総合研究所 環境管理技術研究部門 研究員

(テ305-8569 つくば市小野川16-1) TEL 029-861-8154

National Institute of Advanced Industrial Science and

Technology (AIST)

(16-1 Onogawa, Tsukuba, Ibaraki 305-8569, Japan)

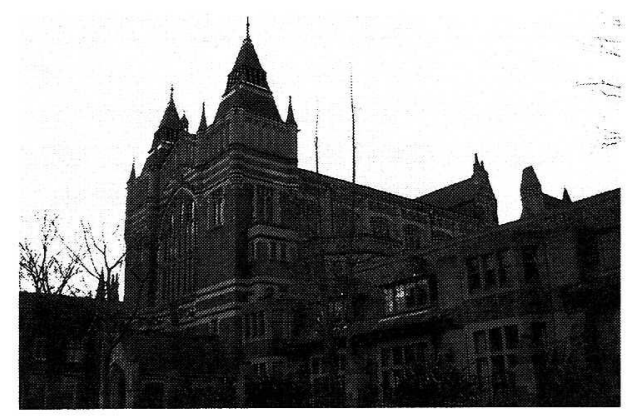

図1リーズ大学の校舎 (Great Hall) 赤レンガが美しい。

経済が上昇，現在はイギリスで最も成長し続けている 都市の一つであろう。滞在中のイギリスは, 至る所で 景気の良さが感じられたが, 街のあちこちでビルディ ングが建設され，次々とウォーターフロントが再開発 されているリーズのダイナミックな発展ぶりは, その 中でもひときわ目を引く。そしてこの好景気のせい か, 物価高には驚かされた。例えばマクドナルドの セットメニューでも 4 ポンド強（約 1000 円，£ $1=$ $¥ 240$ 換算）もするし，借りたフラット（アパート） は 1 ベッドルームの日本並みの広さで月約 600 ポンド (約 14.4 万円, 同) であった。それでも, 大多数のイ ギリス人が日本の方が物価が高いと思っているのだか ら，世界は広いものだ。

リーズ大学は, いわゆる Red Brick と呼ばれる, 19 世紀半ばから 20 世紀初頭にイギリス各地に創設さ れた総合大学の一つである。工学系学科のレベルが特 に高く, 大手新聞の一つGuardian 紙の最新のランキ ングでは, 化学工学部門で 1 位に輝いている。筆者が 所属した Institute of Particle Science and Engineering (IPSE) は, Faculty of Engineering 内の School of Process, Environmental and Materials Engineering (SPEME) に属する研究組織である。親 日家である Mojtaba Ghadiri 教授が Director を務め ておられることもあり，何かと日本との繋がりが深 い。乾式, 湿式, 実験, シミュレーションと, およそあ らゆる分野の粉体関連の研究が行われ, 粒子に特化し た組織としては世界的にも, 米フロリダ大学や豪州メ 
ルボルン大学の研究所と並んでトップレベルにある。

筆者が滞在したのは，IPSEの中でコロイド・界面 工学を担当するSimon Biggs 教授の研究室である。 彼は年齢は 40 代前半とまだ若いが, 原子間力顕微鏡 （AFM）を用いた表面間力の研究で多くの優饥た業績 を残している。研究については非常に精力的だが, 人 柄は陽気で気さく，いつも几談を飛ばしている。ま た, 彼は若くして Faculty of Engineering の副研究 科長も務めている。ちなみにこのような役職は持ち 回りや指名で決まるのではなく, 自薦でしかも候補者 はマニフェストを提出し，それを元にきちんとした面 接や選挙を経て決定されるものらしい。いかにもイギ リスらしい話ではある。

研究室では, 高分子ミセルの吸着と構造制御などの 基礎的な研究から, 濃厚サスペンションのレオロジー やろ過, マイクロカプセル生成などの応用研究まで,

「液相中の微粒子」をキーワードにかなり幅広いテー マが扱われていた。研究室の構成はポスドク 2 名, ド クターコースの学生が $7 \sim 8$ 名で, 国籍は多岐に渡 る。特にポスドクとして, 酒井健一博士（現東京理科 大）が活躍されており，筆者も公私に渡り大変にお世 話になった。このようにIPSEに在籍する職員・学生 は世界各国から人が集まっており，特にアジア系の人 たちが半分以上を占めている。これには驚かされた が，イギリスの現況からはそれほど珍しいことでもな いようだ。

研究室の䨌囲気は大変に自由であった。Simon は, 研究については大まかな方向を示した後は, 各自にか なりの部分を任せていた。そして，毎日暇のある時に 声をかけて回り, 雑談のように研究の話をしながら, 細かい助言や方向修正を行うというスタイルだった。 毎週のミーティングも，コーヒーやお茶，打菓子を持 ち寄って，とてもリラックスした雲囲気の中で行われ ていた。また，結果さえ出していれば，学生は何時に 研究室に来て何時に帰万うが自由なので, 学生は自分 のペースで研究ができる反面，それなりの自己管理も 求められる。筆者の場合も, 渡英前にあらかじめやり たい研究の大まかな方向を伝えてはいたが, 改めて Simonに相談しょうとしたら，「自由にやってくれ」 と言われ，殆ど思うままに研究することができた。最 終的には, Simon を始め研究室の人々とのディスカッ ションのお陰もあり, 表面に固定した温度応答性高分 子の相転移を, AFMによって直接観察したり, 重量 測定装置である水晶振動子マイクロバランス (QCM) を, 高分子の構造変化の評価へ応用したりという， あ まり他に例のない研究に漕ぎ着けることができた。

イギリスで研究をする上で印象に残ったのは，イギ リス人はとてもティィスッションが好きだということ

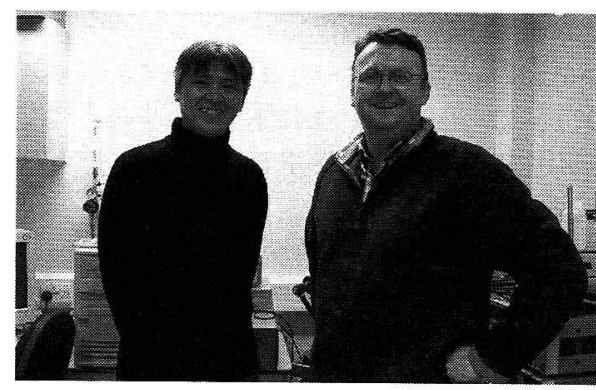

図2 Simon Biggs教授（右）亡筆者

だ。これは欧米人全般に言えることかもしれないが， 研究はもちろん，天気から政治の話に至るまで，一人 一人が確たる自分の意見を持ち，また相手の意見も尊 重しながら，長々と喋っている。学生にしても，意識 は先生と対等で, 立場や知識・経験の差を気にせず, 常に堂々と自分の意見を主張するので, 少々びっくり した。率直に言えば，装置などハード的な面は，イギ リスは全体的に日本よりも劣っている。それにもかか わらず多くの質の高い研究が行われているのは, 自分 の研究について, 納得いくまで何時間でも話し合い, それによって生まれるアイディア，解釈，独自性を大 切にしているからではなからうか。また，常に確たる 自分の意見を持ち，それをきちんと人に伝える，とい う習慣は研究のアピールやプレゼンテーションの上手 さに通じている。日本の研究も内容では全く劣ること はないが, 研究の背景や動向, 必然性などを説得力を 持って語ることで, 研究を魅力的に見せる点では, 言 語的な有利さ以上にイギリスの研究者に一日の長があ る。自分の研究を世界に知ってもらうには, 研究内容 ばかりでなく，それをどうアピールするかも同じよう に重要だと肌で感じたが，こういうバックグラウンド を見るにつけ，習慣の違いが非常に大きな差になって いると思わ机てならない。

筆者はイギリスに来る前には，イギリスの研究環境 もアメリカと同じように競争的で, 成果主義であると 思い込んでいた。しかし，それは少し違うようだ。イ ギリス人にはアメリカ的な考え方，価值観が好きでな い人も多いし，論文数，IF，特許数，というょうに 定量的に研究を評価する傾向は, 日本と比へてても薄い ように思う。それよりも自分の納得のいく研究をし て, 時間がかかっていい論文をじっくり書こうとい う人が多い。また，アメリカに行っても，競争的な雲 囲気を嫌って鹵ってくる研究者も多いとも耳にする。 欧米というカテゴリで一つに括られがちだが，その辺 の雾囲気はアメリカと欧州ではかなり異なっているの ではなかろうか。

またここの年はちょうど SPEME の設立 100 周年に あたり，秋には式典などの記念行事が行われた。筆者 
も外部から来た研究者の代表として, 記念行事の中で リーズでの研究を発表させて頂ける光栄に浴すること ができた。このような大変名誉な機会を与えて下さっ た Ghadiri 教授に心から感謝したい。

\section{3. イギリスでの生活}

\section{1 パブとビール}

イギリスといえば何といってもパブ，ビールであ る。どんな小さな町にもパブがあり，夜は地元の馴染 み客を中心にあらかた満員になる。パブはイギリス文 化の中核をなしていると言っても決して大げさではな い。パブでは飲むばかりでなく，食事をとることがで きる。しかし，夜にはビールだけをちびちびと，ほと んどつまみなしで長時間飲んで過ごすのがスタイルら しい。健康にはとても悪そうだ。ビール腹の男性が多 いのはこのせいだろうか。

イギリスのビールは, 種類がとにかく豊富で美味し い。一杯 1 パイント（約 $568 \mathrm{ml}$ ) という単位で大体 2 〜 4 ポンド，他の物価からすれば安いといえる。大概 のパブでは, 大手会社の定番ビールもとともに, エー ルといわれる上面発酵によって作られるビールが並ん でいる。このエールビールは殆どがいわゆる地ビール で，銘柄により色々な特色があって非常に面白い。研 究室では，毎週金曜日になると皆で建物の向かいにあ るパブに行き，昼食を共にする習慣であった。そのパ ブは, 客の大半が大学の先生・職員・学生で占められ ていたが, みな昼から堂々とビールを飲み, 午後から また仕事をしている。およそ日本では考えられない光 景でびっくりしたが，そういう時には筆者も，ここぞ とばかり異文化の吸収に努めたものだ。

3. 2 サッカーとワールドカップ

イギリスではラグビー（リーズには強豪プロチーム がある）やクリケットも国民的なスポーツとして人気 があるが，サッカーに対する情熱は特別で，生活に欠 かせないもののように感じられる。プレミアリーグを 筆頭に, 各レベルで数多くのチームが存在し, 週末は 「おらが町のチーム」の応援で大変に盛り上がる。ま た，筆者の滞在した年には，ちょうどワールドカップ がドイッで開催され，イングランド代表チームが出 場，かなり期待されていた。当然りーズでもお祭りの ような雲囲気である。家の空や車にはイングランドの 旗が翻り，ニュースも新聞もやれ選手のプレーがどう だ，監督の采配がこうだと連日㗊しい。イングランド の試合の時間ともなると, 試合を見る男性客でパブは 昼間でも超満員, 道を歩いているのは女性かアジア・ 中東系の人たちだけ。試合に勝とうものなら, 代表ユ ニフォームを着て酒に酔った人々が, 街中を練り歩き 応援歌を大合唱の大騒ぎである。大学の研究室では学

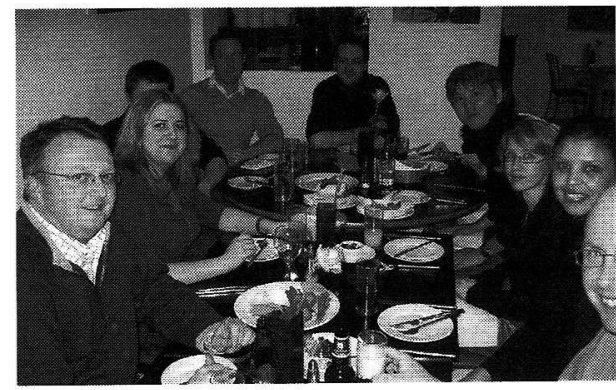

図3研究室の面々

生主催の賭けが公然と? 行われ，イングランドの試合 の日には, 学生は昼からパブやパブリックビューに応 援しに行ったまま帰ってこないのはおろか, Simon や他の研究室の先生でさえも気もそぞろで，いつの間 にか早退してしまうという有様であった。結局イング ランドは決勝トーナメントで惜しくも敗れてしまった が，この盛り上がりようは近代サッカー発祥の地の名 に恥じない?ものであった。

\section{3 古いものを大切にする人々}

イギリス人が古いものを大事にする（しすぎる）と いうのは良く聞くところであるが，こと「住」に関し ては，それが特に実感される。石造りがほとんどであ るため，築百年の家など全く珍しくないし，家は古く なるほど值段が上がるらしい。筆者が最初に借りたフ ラットも，元々は非常に古い石造りの一軒家で，大家 が自分自身で全て改装したものだったが，半地下の倉 庫までモダンなリビングになっていたのには驚嘆させ られた。これは決して特別なことではなく，多くのイ ギリス人は古い家を自分でリフォームし，住みやすい ようにするのに並々なら精力を注いでいるらしい。 有名なガーデニングもこの一部で, 住居の「外側」へ のこだわりであるといえる。

建物に限らず，町並みや郊外の風景なども，昔なが らのものが多い。特に, 郊外の田園地帯は無闇な開発 が入らず，美しい風景が残されている所が非常に多い のが印象的である。これらも，古いものを大事にす る, あるいは, 今あるいいものを極力残す, という姿 勢の現れであろうか。

\section{4 「自由と寛容」の国}

留学前には筆者は, 当然「イギリス =先進国=生活 には困らない」と思っていた。しかし実際に暮らして みると, 大概の商店は午後 $6 \sim 7$ 時には閉まってしま うし，コンビニエンスストアなど数えるほどしかな い。公共の手続きはやたらに時間がかかるし，イン ターネットは遅いし, バスや電車は時間通りに来ず, 郵便はきちんと届かない。街はゴミだらけで污いし， 生活用品の質はひどいものだ。これには面食らった 
し，最初はいらいらさせられた。そういう所だけ見れ ば，「何でも便利でキレイな国，日本」から来た目に は，イギリスは半世紀以上前までの栄光から，すっか り時間が止まっているような感じさえする。

でも，イギリス人を見ていると，そんなことは皆気 にせず，気楽そうなのだ。一生䀣命働いているのに， やれ負け組だの格差だのと，いつも何かに追われてい る日本人と比へ，ストレスなどとは無縁に見える。ど うしてあんなに気楽に，リラックスして生活できるの だろう? 自分自身も，イギリスの空気に触れて呼吸が 安らぐような思いで過ごせたのはなぜだろう？

たぶんそれは，イギリス社会の根本にある寛容さ一 あるいは「ゆるさ」にあるのではなかろうか。イギリ ス人と接して印象に残るのは, 彼らは確かに個人主義 で，人は人，自分は自分なのだけれど，確固として自 分の自由を重んじる分，人にもとても寛容だ。ほとん ど「適当」といっても良いくらいだ。電気やガスが止 まっても，バスや電車が盛大に遅れても，人々はあま り怒ったりもせず，淡々としている（もう諦めてい る，という見方もあるけれど)。自分も自由に，適当 に行動する代わりに，人の行動にもとやかくは言わな い。意見の違いはあっても，価値観の違いが攻撃され ることはない。この自由で寛容な気質は, 色々問題も 生み出しているけれど, 一方で社会をとても居心地良 く感じさせていることも確かだ。これが, たくさんの 移民や違う文化を受け入れてきた土台なのだろうか。 それとも逆だろうか。

そして，その寛容さと地続きにあるのが，人と人の 間の垣根の低さだ。道に迷えば必ず誰かが声をかけて くれるし，こちらはどう見ても外国人なのに平気で道 を聞いてくる。店で買い物をすれば隣のご婦人が「そ の商品はいいわよ，私もこの前それを買ってねえ゙...」 と延々と話しかけてくるし，鉄道で 4 人がけの席にな れば，知らない同士でも話に花が咲き始める。そし て，こういった人と人の関係は，イギリスあるいは ヨーロッパ的な相互扶助精神に昇華している。それは 福祉とか寄付といったこともあるけれど，それよりも っと些細な，目立たないことにこそ，その本質がある ように思うのだ。例えばバスを降りるときには必ず運 転手にお礼を言い，建物では後の人のためにドアを押 さえ，道は譲り合い，ぶつかったら目を見て “sorry” と言いあい, 車椅子には手を貸し, 優先席はすぐに誰 り，道で打年寄りが転んだらすぐに誰かが助ける，と いったように。とても些細なことばかりだが，これら はなるへくく互いが気持ちよく生きていくための「知 恵」ともいえる。とても残念なことに，日本でこうい う光景を目にすることは年々急激に減っているのだけ れど,ここでは誰もがとても自然に，さりげなく人に
手を差し出している。基本的に人は人，なのだけれ ど，他人への助けも惜しまない。それぞれが自分の思 うまま，少しずつ手を差し伸べあうことによって，結 果的に皆が少しずつハッピーになっている。ステレオ タイプな見方では,「欧米」の個人主義は, 時として 自分勝手なギスギスした状態を作ると思われがちだ。 しかしここで目にしたのは，それとは少し異なる， もっとゆるくて人間くさい社会だった。

だからといって，もちろんイギリスは約束の地では ないし，たった 1 年住んだだけでも，多くの問題はよ く見える。鿵然たる差別や階級差はまだ存在するし， マナ一の低下, 頽廃的な行動も若い世代に多い。「子 供を育てるのに一番ふさわしくない国」のレッテルを 貼られた教育やドラッグの問題も深刻だし，医療サー ビスは甚だしい質の低下が叫ばれている。しかし，そ れでもパブで昼からビールを飲み，サッカーに一喜一 憂して笑っていられる人々を見るにつけ，それも悪く ないと感じずにはいられない。どうにも「テキトー」 にしか見えないこの国の背骨に培われているものは, とても豊かで，堅军なのであった。

\section{4.おわりに}

今改めて振り返ると, この留学では, 思い描いてい たよりも遥かにたくさんのことを学んだように思う。 もちろん, 雑事から離れて研究に没頭できたことは大 きかった。しかしそれよりも，曲がりなりにも外国で 1 年間暮らしたという，その経験は想像以上だった。 本欄に滞在記を寄せられた先輩諸氏もそうであったろ うと思うが，言語や文化，習慣の異なる環境で暮らす ためには，やはり大なり小なりの苦労が当然つきまと う。言葉が分からなくてもギリギリのコミュニケーシ ョンを取らざるを得ない場面にも遭遇するし，習慣や やり方の違いから来るストレスも少なくはない。しか し，それらを越えることで，異なるバックグラウンド の人達と理解し合い, 主張し合い, そして尊敬し合う ために，言語そのもの以上に何が必要か，多くのこと を学べたと思う。大げさに言えば，生きていくための 基本的なスキルが, 多少なりとも磨かれた，とでも言 おうか。この体験を糧に，また日々少しでも精進して いきたい。

最後に, 滞在中大変お世話になった Simon Biggs 教授, 酒井健一博士をはじめグループの皆様に感謝し ます。また，何かにつけ気にかけて下さった Mojtaba Ghadiri 教授, 留学前に相談に乗っていただいた京大 東谷公教授, そして, 留学を認め快く送り出して下 さった産業技術総合研究所リサイクル基盤技術研究グ ループの小林幹男リーダーをはじめグループの皆様 に，この場を借りて厚く御礼申し上げます。 